\title{
Crystal Structure and Supramolecular Architecture of Antiallergic Diphenylene Diethyl Dioxalamates
}

\author{
Juan Saulo González-González ${ }^{1, * \mathbb{D}}$, Nancy Evelyn Magaña-Vergara ${ }^{2}$, \\ Efrén Venancio García-Báez ${ }^{3}$, Itzia Irene Padilla-Martínez ${ }^{3}$, Juan Pablo Mojica-Sánchez ${ }^{4}$ (D) \\ and Francisco Javier Martínez-Martínez ${ }^{2, *(D)}$ \\ 1 Instituto de Farmacobiología, Universidad de la Cañada, Carretera Teotitlán-San Antonio Nanahuatipan \\ km 1.7 s/n., Teotitlán de Flores Magón, Oaxaca 68540, Mexico \\ 2 Facultad de Ciencias Químicas, Universidad de Colima, km 9 Carretera Colima-Coquimatlán, Coquimatlán, \\ Colima 28400, Mexico; nancymv@ucol.mx \\ 3 Laboratorio de Química Supramolecular y Nanociencias, Instituto Politécnico Nacional-UPIBI, \\ Av. Acueducto s/n Barrio la Laguna Ticomán, Ciudad de México 07340, Mexico; \\ efren1003@yahoo.com.mx (E.V.G.-B.); ipadillamar@ipn.mx (I.I.P.-M.) \\ 4 Tecnológico Nacional de México, Instituto Tecnológico José Mario Molina Pasquel y Henríquez Campus \\ Tamazula de Gordiano, Carretera Tamazula-Santa Rosa No. 329, Tamazula de Gordiano, \\ Jalisco 49650, Mexico; mojica_sanchez@ucol.mx \\ * Correspondence: juan_saulo@unca.edu.mx (J.S.G.-G.); fjmartin@ucol.mx (F.J.M.-M.)
}

Received: 23 October 2020; Accepted: 16 November 2020; Published: 18 November 2020

\begin{abstract}
The crystal structure and the supramolecular architectures of the antiallergic compounds $N, N^{\prime}$-(4,4'-methanediyl-di-phenyl)-bis-diethyl dioxalamate (1); $N^{\prime}, N^{\prime}$-(4,4'-oxydi- $p$ phenylene)-bis-diethyl dioxalamate (2); $N, N^{\prime}$-(4,4'-biphenylene)-bis- diethyl dioxalamate (3) are reported. The supramolecular self-assembly in 1-3 is driven by $\mathrm{N}-\mathrm{H} \cdots \mathrm{O}=\mathrm{C}$ hydrogen bonds and reinforced by $\mathrm{C}-\mathrm{H} \cdots \mathrm{O}=\mathrm{C}, \mathrm{C}-\mathrm{H} \cdots \pi$ and $\mathrm{C}=\mathrm{O} \cdots \mathrm{C}=\mathrm{O}$ interactions. The three compounds preferred to form cross-linked supramolecular architectures. Intermolecular interactions also were studied by the Hirshfeld surface analysis, revealing that the $\mathrm{H} \cdots \mathrm{H}, \mathrm{O} \cdots \mathrm{H}$, and $\mathrm{C} \cdots \mathrm{H}$ are the more dominant contacts in the three compounds. The knowledge of crystal structure will allow us to perform theoretical studies to evaluate the antiallergic activity of compounds 1-3.
\end{abstract}

Keywords: diphenylene bis-diethyl dioxalamates; hydrogen bond; Hirshfeld surface analysis; crystal structure

\section{Introduction}

Allergic conjunctivitis is a disease characterized by the ocular conjunctiva inflammation. It is associated with the degranulation of sensitized mast cells, and is caused by dust, smoke, pollens, chemical vapors, solvents, and environmental antigens. Some symptoms of ocular allergy are itching, tearing, lid and conjunctival edema-redness, and photophobia during the acute phase [1,2].

Therapeutic options for treatment of allergic conjunctivitis are topical steroids, antihistamines, and mast cell stabilizers. Lodoxamide is a phenylene bis-oxalamidic compound that acts as mast cell stabilizer by stopping the $\mathrm{Ca}^{2+}$ flux during the activation of mast cells, inhibiting their degranulation [3].

Phenylene bis-oxalamidic compounds (phenylene bis-dioxalamates and phenylene bis-dioxalamides) have functional groups ( $\mathrm{N}-\mathrm{H}, \mathrm{C}=\mathrm{O}$ and aromatics) capable of forming hydrogen bond interactions, which make them interesting for the study of supramolecular self-assembly. Our research group has focused on the molecular and supramolecular studies of phenylene bis-ethyl dioxalamates, phenylene bis-oxalamides, and phenylene bis-thiooxalamides, involving studies such 
as: three-centered hydrogen bonding, solid state polymorphism, effect of steric restraints, host-guest complexes, and supramolecular self-assembly [4-9]. Supramolecular architectures of phenylene bis-diethyl dioxalamates are driven by $\mathrm{N}-\mathrm{H} \cdots \mathrm{O}=\mathrm{C}$ and $\mathrm{C}=\mathrm{O} \cdots \mathrm{H}-\mathrm{O}$ supramolecular synthons, which give rise to well-defined hydrogen bonding supramolecular patterns, such as tapes, sheets, columns, and helical supramolecular architectures [6-12]. Thus, the understanding of these intermolecular interactions is of great interest in the design of new compounds with applications in supramolecular chemistry [7], metallosupramolecular chemistry [13-15], gelling agents [16] and pharmaceutical cocrystal coformers [17].

Allergic reactions start when the allergens bind with the FceRI receptor of immunoglobulin E ( $\operatorname{IgE})$, triggering the signals transduction reaction in mast cells and basophil cells, releasing inflammatory mediators [18,19]. Diphenylene diethyl dioxalamates 1-3 were reported and patented as antiallergic compounds [20-22]; however, there is no information about their crystal structure and supramolecular study. In this work, we report the crystal structure and the supramolecular study of three diphenylene bis-diethyl dioxalamates (1-3) (Figure 1). In addition, the intermolecular contacts present in the crystal packing were analyzed by the Hirshfeld surface plots [23]. The knowledge of the molecular structure of 1-3 compounds will allow the development of further studies to evaluate theoretically (docking studies) the antiallergic activity of 1-3 compounds.
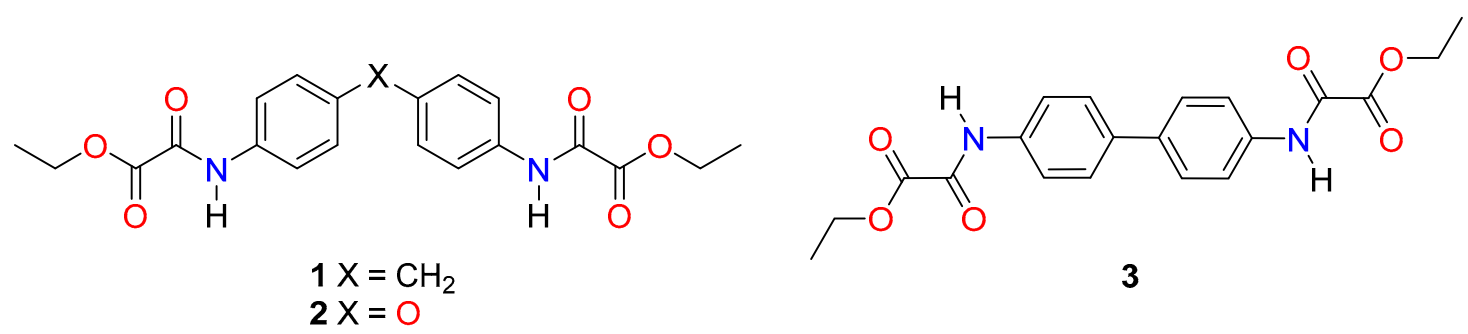

Figure 1. Diphenylene bis-diethyl dioxalamates in this study.

\section{Materials and Methods}

\subsection{Crystallization of Compounds 1-3}

Compounds 1-3 are known [20-22]; they were prepared by reacting the corresponding diphenyl diamine with ethyl 2-chloro-2-oxoacetate in the presence of triethylamine (TEA) [4] (see Supplementary Materials). All the reagents were purchased from Aldrich (St. Louis, MO, USA).

Single crystals of 1 were obtained from the evaporation at room temperature of the filtered THF solution obtained after the reaction of 4,4'-diaminodiphenylmethane with ethyl 2-chloro-2-oxoacetate, meanwhile, single crystals of $\mathbf{2}$ and $\mathbf{3}$ were obtained from de evaporation at room temperature of THF solutions of purified 2 and 3 . In the three cases, the THF used was not dried.

\subsection{X-ray Diffraction}

A summary of collection and refinement parameters of 1-3 crystal structures is listed in Table 1. Single crystal X-ray diffraction of $\mathbf{1}$ and $\mathbf{3}$ were carried out using a Bruker APEXII with Mo K $\alpha$ radiation $(\lambda=0.71073 \AA)$ diffractometer (Bruker, Karlsruhe, Germany), and 2 with a Nonuis Kappa CCD with Mo $K \alpha$ radiation $(\lambda=0.71073 \AA$ ) (Bruker, Karlsruhe, Germany). The cell refinement and data reduction were carried out with the SAINT V8.34A [24]. The structure was solved by direct methods using SHELXL97 [25]. Mercury software [26] was used to prepare the material for publication. H atoms on C and $\mathrm{N}$ were geometrically positioned and treated as riding atoms with $\mathrm{C}-\mathrm{H} 0.95-0.99 \AA, U_{\text {iso }}(\mathrm{H})=1.2$ $U_{\text {eq }}(\mathrm{C})$ or $1.5 U_{\text {eq }}(\mathrm{C}) ; \mathrm{N}-\mathrm{H}=0.88 \AA, U_{\mathrm{iso}}(\mathrm{H})=1.2 U_{\text {eq }}(\mathrm{N})$. The O-ethyl fragment of compound 2 was disordered over two positions. Both components were refined using restraints applied to the bond distances; the final occupancy factors were 0.612 (18): 0.388 (18) [27]. 
Table 1. Crystallographic data and refinement for 1-3.

\begin{tabular}{cccc}
\hline Parameter & $\mathbf{1}_{\mathbf{2}} \bullet \frac{1}{2}\left(\mathbf{C}_{2} \mathbf{H}_{2} \mathbf{O}_{4}\right) \bullet \mathrm{H}_{\mathbf{2}} \mathbf{O}$ & $\mathbf{2}$ & $\mathbf{3}$ \\
\hline CCDC & 795132 & 795130 & 795134 \\
Chemical formula & $2\left(\mathrm{C}_{21} \mathrm{H}_{22} \mathrm{~N}_{2} \mathrm{O}_{6}\right) \bullet 0.5\left(\mathrm{C}_{2} \mathrm{H}_{2} \mathrm{O}_{4}\right) \bullet \mathrm{H}_{2} \mathrm{O}$ & $\mathrm{C}_{20} \mathrm{H}_{20} \mathrm{~N}_{2} \mathrm{O}_{7}$ & $2\left(\mathrm{C}_{20} \mathrm{H}_{20} \mathrm{~N}_{2} \mathrm{O}_{6}\right)$ \\
$M_{\mathrm{r}}$ molecular weight & 859.84 & 400.38 & 768.77 \\
Crystal system, space group & Triclinic, $P-1$ & Orthorhombic, Pbnb & Triclinic, $P-1$ \\
Temperature $(\mathrm{K})$ & 173 & 173 & 293 \\
$a, b, c(\AA)$ & $10.455(2), 13.174(3), 16.443(3)$ & $7.9088(2), 8.5779(3)$, & $8.5431(11), 10.7978$ \\
& & $28.4375(9)$ & $(13), 16.105(2)$ \\
$\alpha, \beta, \gamma\left({ }^{\circ}\right)$ & $87.97(3), 81.08(3), 70.51(3)$ & $90,90,90$ & $108.892(2), 93.354(2)$, \\
$V\left(\AA^{3}\right)$ & $2108.9(8)$ & $1929.23(10)$ & $90.916(2)$ \\
$Z$ & 2 & 4 & $1402.3(3)$ \\
Crystal size $(\mathrm{mm})$ & $0.40 \times 0.30 \times 0.25$ & $0.50 \times 0.35 \times 0.21$ & 3 \\
$T_{\min }, T_{\max }$ & $0.861,0.862$ & $0.861,0.862$ & $0.48 \times 0.44 \times 0.39$ \\
No. of measured, independent & & & $0.861,0.862$ \\
and observed $[I>2 \sigma(I)]$ & $20,384,7437,6380$ & $5598,1973,1380$ & $13,452,4922,4303$ \\
reflections & & & \\
$R_{\text {int }}$ & 0.026 & 0.033 & 0.029 \\
$(\sin \theta / \lambda) \max \left(\AA^{-1}\right)$ & 0.595 & 0.65 & 0.595 \\
$R\left[F^{2}>2 \sigma\left(F^{2}\right)\right], w R\left(F^{2}\right), S$ & $0.051,0.123,1.12$ & $0.056,0.141,1.06$ & $0.064,0.167,1.13$ \\
No. of reflections & 7437 & 1973 & 4922 \\
No. of parameters & 591 & 160 & 379 \\
No. of restraints & 4 & 6 & 0 \\
$\Delta \rho_{\text {max }} \Delta \rho_{\min }\left(\mathrm{e} \AA^{-3}\right)$ & $0.18,-0.20$ & $0.13,-0.12$ & $0.25,-0.25$ \\
\hline
\end{tabular}

\subsection{Computational Details}

Geometry optimizations of 1-3 were performed in their anti and syn (Figure 2) conformations within the framework of the density functional theory in ORCA computational package [28], using a def2-TZVP basis set [29,30]. For the exchange and correlation, the $\omega$ B97X-D3 functional [31] was employed. These systems where evaluated in vacuum within the Conductor-like Polarizable Continuum Model (CPCM) [32,33]. All minimal energy states were verified with a calculation of harmonic vibrational frequencies, finding only positive values. The images were rendered by the molecular visualizer Chemcraft [34].
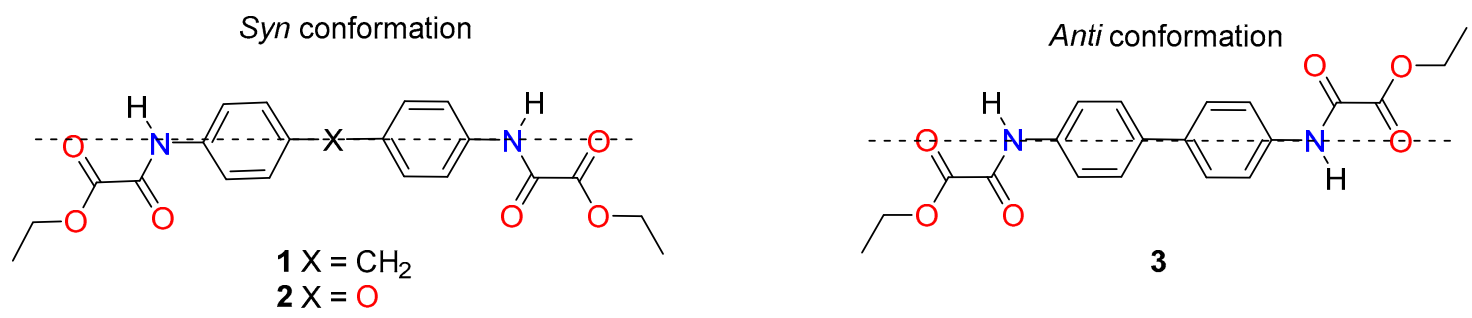

Figure 2. Conformations adopted by the ethyl oxalamate groups in 1-3.

The Hirshfeld surfaces and 2D fingerprints calculations were obtained in Crystal Explorer 3.1 [35] using a Thakkar basis set [36] and employing CIF's archives collected of 1-3 crystal structures. The graphs of Hirshfeld's molecular surfaces were mapped with $d_{\text {norm }}$ using a scheme colors, where the red one represents the shortest contacts, the white color indicates intermolecular distances close to the van der Waals contacts with $d_{\text {norm }}$ equal to zero, and the blue color shows the contacts longer than the sum of the van der Waals radii with positive $d_{\text {norm }}$ values $[23,37]$.

\section{Results and Discussion}

\subsection{Crystal Structure of Compounds 1-3}

The two ethyl oxalamate groups in each molecule can adopt the syn or anti conformation, depending on their position relative to the perpendicular plane of the diphenyl rings (Figure 2). In the 
crystal structures of $\mathbf{1}$ and $\mathbf{2}$ the syn conformation is adopted, whereas in $\mathbf{3}$ the anti conformation is observed. The ethyl oxalamate side arms are twisted from the mean plane of the phenyl ring showing torsion angles ranging from $152^{\circ}$ to $166^{\circ}$.

In compounds 1-3, the carbonyl groups of the $\mathrm{C}=\mathrm{O}-\mathrm{C}=\mathrm{O}$ fragment adopt the ant $i$ conformation usually observed in oxalic acid derivatives [4-8], with torsion angles ranging from $162^{\circ}$ to $178^{\circ}$ (Table S1 Supporting Materials). Intramolecular hydrogen bonding allows the formation of $S(5)$ and $S$ (6) motifs [38] whose geometric parameters are listed in Table S2 of Supporting Materials.

Cocrystal $\mathbf{1}_{2} \bullet \frac{1}{2}\left(\mathrm{C}_{2} \mathrm{H}_{2} \mathrm{O}_{4}\right) \bullet \mathrm{H}_{2} \mathrm{O}$ crystallized in the triclinic space group P-1. In the unit cell, four molecules of $\mathbf{1}$ co-crystallized with one molecule of oxalic acid and two water molecules. Oxalic acid and water were unexpectedly incorporated into the crystalline lattice from the synthesis residues and the not dried solvent, respectively. The asymmetric unit comprises two independent molecules of $\mathbf{1}$ (1a and $\mathbf{1} \mathbf{b}$, Figure 3), one molecule of water, and the molecule of oxalic acid lying on the center of symmetry. The torsion angles between the planes of the phenyl rings for the twin independent molecules of 1 are quite different: C4-C13-C17-C16 is $-86.4(2)^{\circ}$ and C29-C38-C42-C43 is 43.0(3) ${ }^{\circ}$ around the $\mathrm{O}=\mathrm{C}-\mathrm{C}=\mathrm{O}$ group, for $\mathbf{1 a}$ and $\mathbf{1 b}$, respectively. Compound $\mathbf{1}$ is non-linear, with the $\mathrm{Ar}-\mathrm{CH}_{2}-\mathrm{Ar}$ angles being 111.1(2) ${ }^{\circ}$ (C4-C13-C17) for $\mathbf{1 a}$ and 115.9(2) ${ }^{\circ}$ (C29-C38-C42) for $\mathbf{1 b}$. These values are in agreement with the reported values for similar compounds [39,40]. The ethyl oxalamate groups are somewhat twisted out of the plane of the aromatic ring, as can be seen from the torsion angles $\mathrm{C} 2-\mathrm{C} 1-\mathrm{N} 7-\mathrm{C} 8=$ $-152.1(2)^{\circ}, \mathrm{C} 15-\mathrm{C} 14-\mathrm{N} 20-\mathrm{C} 21=-166.8(2)^{\circ}, \mathrm{C} 27-\mathrm{C} 26-\mathrm{N} 32-\mathrm{C} 33=178.0(2)^{\circ}$, and C44-C39-N45-C46 = $175.4(2)^{\circ}$.
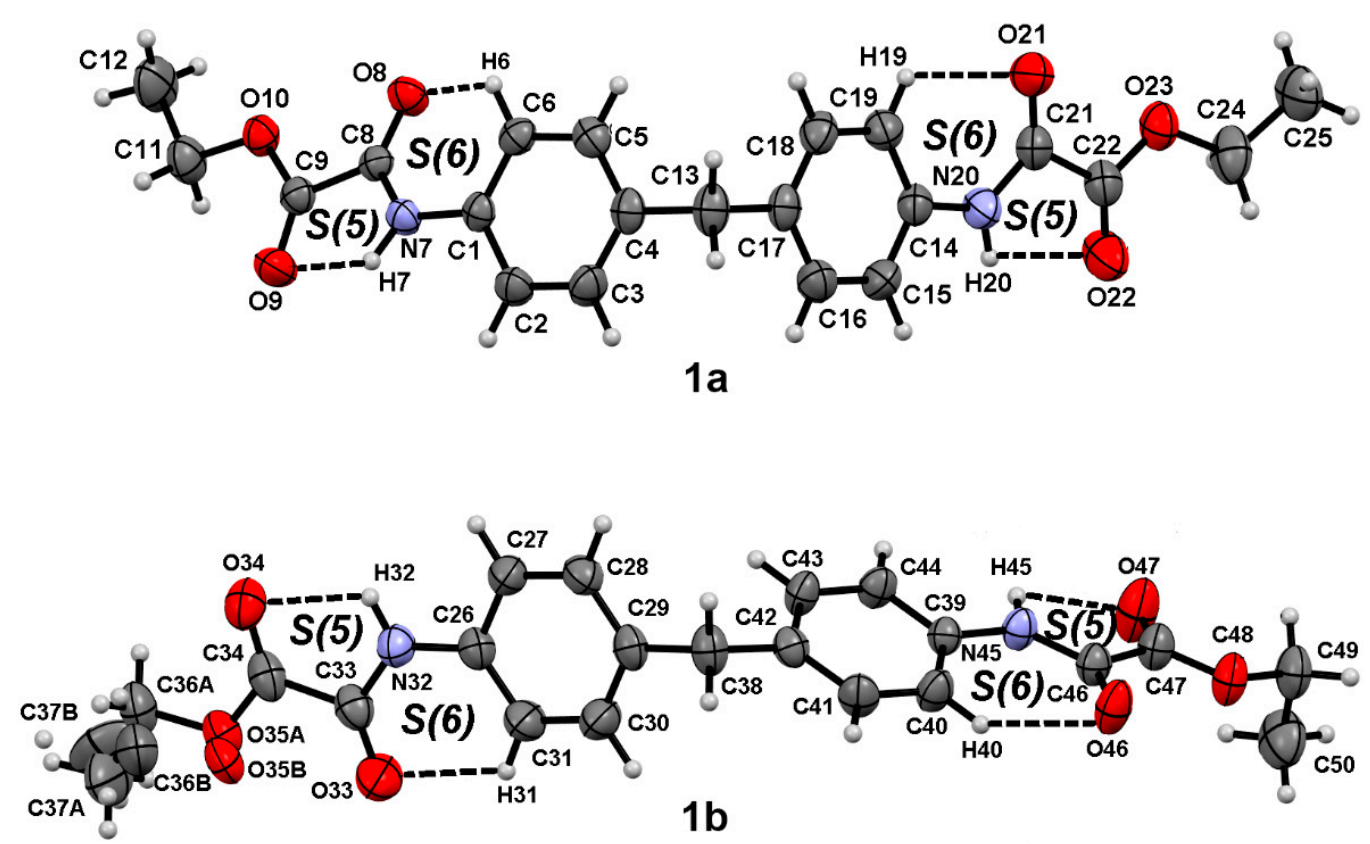

Figure 3. Molecular structure of $\mathbf{1 a}$ and $\mathbf{1} \mathbf{b}$ at $30 \%$ of probability level showing the atom numbering scheme and the intramolecular interactions.

Compound 2 (Figure 4) crystallizes in the orthorhombic space group Pbnb, with the molecule lying across a two-fold axis, having $C_{2}$ symmetry, thus only one half of the molecule is present in the asymmetric unit with $A r-\mathrm{O}-\mathrm{Ar}$ angle of $118.6(2)^{\circ}$ (C4-O13-C4). The $\mathrm{O}=\mathrm{C}-\mathrm{C}=\mathrm{O}$ and $\mathrm{C} 2-\mathrm{C} 1-\mathrm{N} 7-\mathrm{C} 8$ torsion angles are $-165.4(2)^{\circ}$ and $-16.3(3)^{\circ}$, respectively, with the OEt group lying out of the plane of the oxalamate group. 


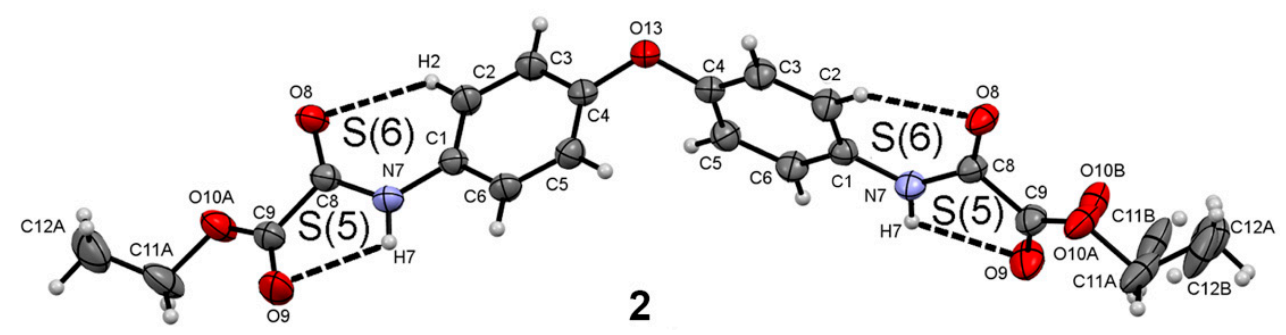

Figure 4. Molecular structure of 2 at $30 \%$ of probability level showing the atom numbering scheme and the intramolecular interactions.

Compound 3 crystallized in the space group $P-1$, with three molecules in the unit cell; the asymmetric unit (Figure 5) contains one complete molecule ( $\mathbf{3 b}$ ) and one half of a second centrosymmetric molecule (3a). The absence of the spacer group between the aromatic rings results in the linear alignment of the phenyl rings. The phenyl rings in 3a are almost coplanar, the torsion angle $\mathrm{C} 3-\mathrm{C} 4-\mathrm{C} 4^{\prime}-\mathrm{C}^{\prime}$ is $2.0(5)^{\circ}$ while the phenyl rings in $\mathbf{3 b}$ is significantly twisted with torsion angle C23-C24-C44-C45 of 14.1(4) ${ }^{\circ}$. The ethyl oxalamate groups are slightly out of the mean plane of the phenyl ring with torsion angles C2-C1-N7-C8 of $-166.8(3)^{\circ}$ in 3a and C22-C21-N27-C28 and C42-C41-N47-C48 of $-157.0(2)^{\circ}$ and $-164.8(2)^{\circ}$, respectively.
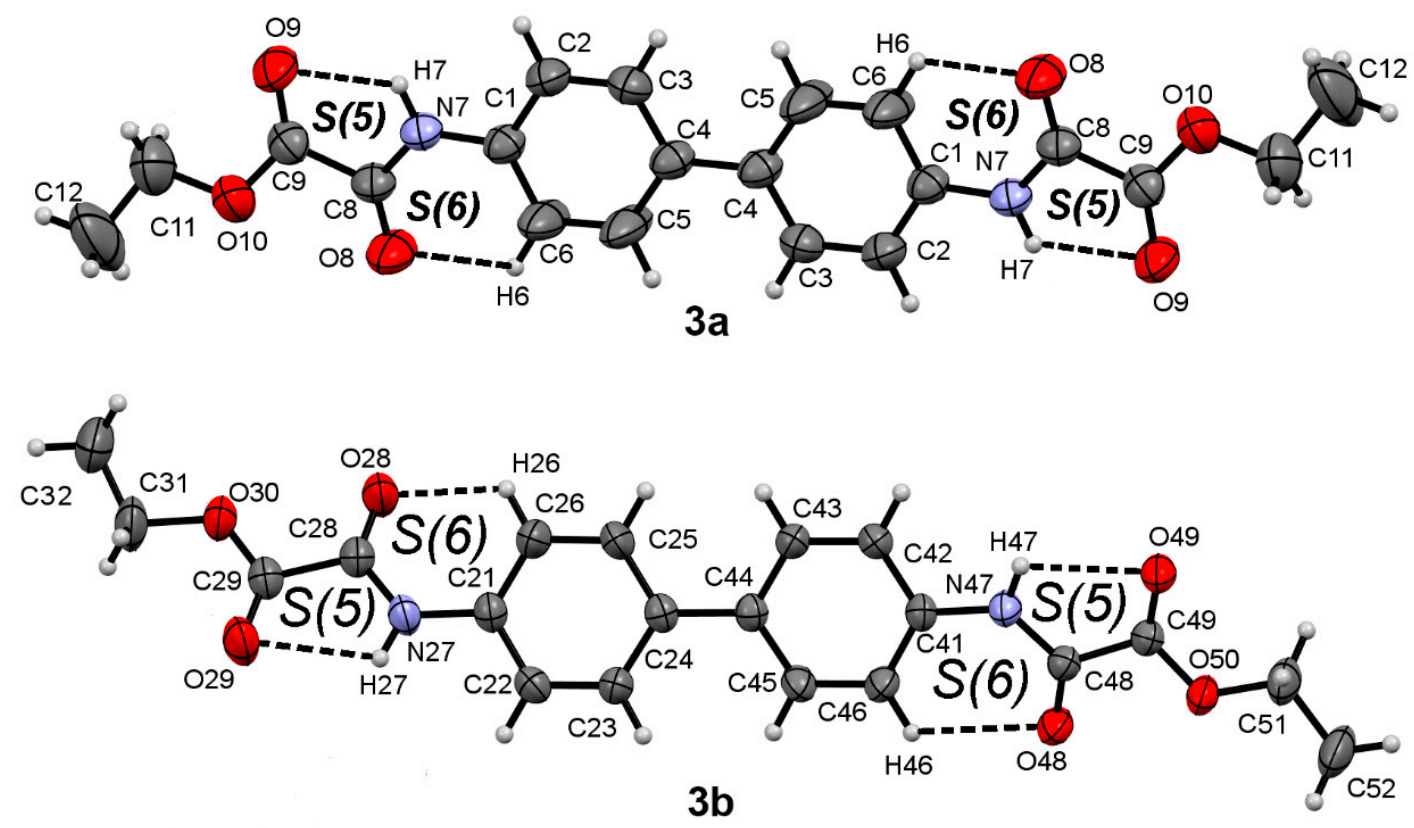

Figure 5. Molecular structure of $\mathbf{3 a}$ and $\mathbf{3 b}$ at $30 \%$ of probability level showing the atom numbering scheme and the intramolecular interactions.

\subsection{Supramolecular Architectures of $\mathbf{1}_{2} \bullet \frac{1}{2}\left(\mathrm{C}_{2} \mathrm{H}_{2} \mathrm{O}_{4}\right) \bullet \mathrm{H}_{2} \mathrm{O}$ and 2-3}

The geometric parameters associated with hydrogen bonding and non-covalent intermolecular interactions of cocrystal $\mathbf{1}_{2} \bullet \frac{1}{2}\left(\mathrm{C}_{2} \mathrm{H}_{2} \mathrm{O}_{4}\right) \bullet \mathrm{H}_{2} \mathrm{O}$ and compounds 2-3 are summarized in Table 2 . Classic hydrogen bonding [41], $\mathrm{C}-\mathrm{H} \cdots \mathrm{O}$ [42], $\mathrm{C}-\mathrm{H} \cdots \pi$ [43] or $\mathrm{C}=\mathrm{O} \cdots \mathrm{O}=\mathrm{C}$ [44] interactions are in agreement with accepted criteria. The patterns of hydrogen bonds are described according the graph set notation [38]. 
Table 2. Intermolecular interactions for $\mathbf{1}_{2} \bullet \frac{1}{2}\left(\mathrm{C}_{2} \mathrm{H}_{2} \mathrm{O}_{4}\right) \bullet \mathrm{H}_{2} \mathrm{O}$ and 2-3.

\begin{tabular}{|c|c|c|c|c|c|}
\hline Comp. & $\mathrm{D}-\mathrm{H} \cdots \mathrm{A}$ & $\mathrm{D}-\mathrm{H} / \mathrm{A}$ & $\mathrm{H} \cdots \mathrm{A} / \mathrm{A}$ & $\mathrm{D} \cdots \mathrm{A} / \mathrm{A}$ & $\mathrm{D}-\mathrm{H} \cdots \mathrm{A} /^{\circ}$ \\
\hline \multirow[t]{11}{*}{$\mathbf{1}_{\mathbf{2}} \bullet \frac{1}{2}\left(\mathrm{C}_{2} \mathrm{H}_{2} \mathrm{O}_{4}\right) \bullet \mathrm{H}_{2} \mathrm{O}$} & $\mathrm{N} 7-\mathrm{H} 7 \cdots \mathrm{O} 60^{i}$ & 0.88 & 2.16 & $2.980(2)$ & 154 \\
\hline & $\mathrm{N} 20-\mathrm{H} 20 \cdots \mathrm{O} 34^{i i}$ & 0.88 & 2.24 & $3.045(2)$ & 151 \\
\hline & $\mathrm{N} 32-\mathrm{H} 32 \cdots \mathrm{O} 22^{i i}$ & 0.88 & 2.37 & $3.153(3)$ & 148 \\
\hline & $\mathrm{N} 45-\mathrm{H} 45 \cdots \mathrm{O} 8^{i}$ & 0.88 & 2.22 & $3.063(2)$ & 159 \\
\hline & $\mathrm{N} 45-\mathrm{H} 45 \cdots \mathrm{O} 10^{i}$ & 0.88 & 2.45 & $3.037(2)$ & 125 \\
\hline & O61-H61‥O70 & 0.84 & 1.73 & $2.569(2)$ & 178 \\
\hline & O70-H70A $\cdots \mathrm{O} 8$ & 0.86 & 2.02 & $2.864(2)$ & 167 \\
\hline & O70-H70B $\cdots \mathrm{O}^{4} 6^{i i i}$ & 0.82 & 2.03 & $2.819(2)$ & 159 \\
\hline & O70-Н70B $\cdots$ O $48^{i i i}$ & 0.82 & 2.54 & $3.141(2)$ & 131 \\
\hline & $\mathrm{C} 44-\mathrm{H} 44 \cdots \mathrm{O} 8^{i}$ & 0.95 & 2.56 & $3.367(3)$ & 143 \\
\hline & $\mathrm{C} 18-\mathrm{H} 18 \cdots \mathrm{Cg}(1)^{v}$ & 0.95 & 3.018 & 3.848 & 147 \\
\hline \multirow[t]{2}{*}{2} & 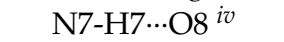 & 0.86 & 2.29 & $3.082(2)$ & 154 \\
\hline & $\mathrm{C} 3-\mathrm{H} 3 \cdots \mathrm{Cg}(2){ }^{i x}$ & 0.93 & 3.268 & 4.104 & 151 \\
\hline \multirow[t]{6}{*}{3} & 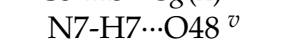 & 0.86 & 2.20 & $3.019(3)$ & 158 \\
\hline & $\mathrm{N} 27-\mathrm{H} 27 \cdots \mathrm{O} 49^{v i}$ & 0.86 & 2.50 & $3.232(3)$ & 143 \\
\hline & $\mathrm{C} 2-\mathrm{H} 2 \cdots \mathrm{O} 48^{v i i i}$ & 0.93 & 2.44 & $3.210(3)$ & 140 \\
\hline & $\mathrm{C} 22-\mathrm{H} 22 \cdots \mathrm{O} 49^{v i}$ & 0.93 & 2.54 & $3.374(3)$ & 149 \\
\hline & $\mathrm{C} 12-\mathrm{H} 12 \mathrm{C} \cdots \mathrm{Cg}(2)^{x}$ & 0.98 & 3.285 & 9.979 & 131 \\
\hline & $\mathrm{C} 32-\mathrm{H} 32 \mathrm{~B} \cdots \mathrm{Cg}(2)^{x i}$ & 0.96 & 3.213 & 4.012 & 142 \\
\hline
\end{tabular}

Symmetry codes: (i) -x+1,-y+1,-z; (ii) -x+1,-y+2,-z+1; (iii) $x-1, y+1, z$; (iv) $-x+1 / 2, y+1 / 2, z$; (v) $x-1, y, z$; (vi) $x-1, y-1, z$; (vii) $-\mathrm{x}+3,-\mathrm{y}+1,-\mathrm{z}+1$; (viii) $\mathrm{x}-1, \mathrm{y}, \mathrm{z}$; (ix) x,-1/2+y,1/2-z; (x)-x,1-y,-z; (xi) 1-x,1-y,1-z. Cg(1) = C26-C31, Cg(2) = C1-C6.

The zero dimensional array ( 0 -D) of $\mathbf{1}_{\mathbf{2}} \bullet \frac{1}{2}\left(\mathrm{C}_{2} \mathrm{H}_{2} \mathrm{O}_{4}\right) \bullet \mathrm{H}_{2} \mathrm{O}$ is given by pairing $\mathbf{1 a}$ and $\mathbf{1} \mathbf{b}$ molecules

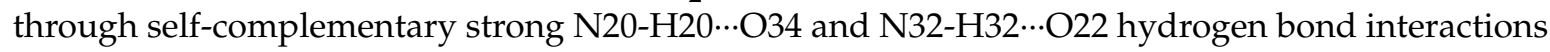
depicting a $R_{2}^{2}(10)$ motif, similar to the diethyl $N, N^{\prime}-m$-phenylenedioxalamate [10]. These hydrogen bonded $1 \mathbf{a}-1 \mathbf{b}$ pairs are linked by a set of three-centered hydrogen bond interactions $\mathrm{O} 8 \cdots \mathrm{H} 45 \cdots \mathrm{O} 10$

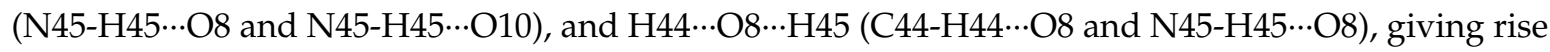
to $R^{2}{ }_{1}(5)$ and $R^{1}{ }_{2}(6)$ motifs, respectively. Water molecules, hydrogen bonded to the oxalic acid

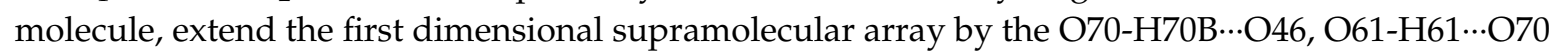
hydrogen bonds depicting a supramolecular tape running along the $b$ axis (Figure 6a). Propagation of the supramolecular tape by C-H $\cdots \pi(\mathrm{C} 18-\mathrm{H} 18 \cdots \mathrm{Cg}(1)=3.018 \AA, \mathrm{Cg}(1)=\mathrm{C} 26-\mathrm{C} 31)$ and $\mathrm{C}=\mathrm{O} \cdots \mathrm{C}=\mathrm{O}$ interactions $(\mathrm{C} 21-\mathrm{O} 21 \cdots \mathrm{C} 34=2.931(3) \AA)$ give rise to a supramolecular sheet extended in the $b c$ plane, (Figure 6b).

The third dimension is extended by lone pair $\rightarrow \pi$ interactions (C8-O8 $\cdots C g(2)=3.559 \AA$ \& $C g(2)$ = C1-C6) giving rise to a cross linked supramolecular array. This architecture is similar to the supramolecular arrangement of dimethyl-4,4-methylene-bis(phenylcarbamate) [40]. The presence of oxalic acid and water in the unit cell offer a greater possibility of intermolecular interactions. Despite this, it is worth noting that the characteristic amide-amide $R_{2}^{2}(10)$ motif remains as the driving interaction, in the self-assembly of $\mathbf{1}$, together with the three centered $R^{2}{ }_{1}(5)$ and $R^{1}{ }_{2}(6)$ interactions.

The supramolecular architecture of $\mathbf{2}$ is given by the self-assembly of 3:1 repetition units of $\mathbf{2}$, depicting a cross-linked supramolecular array. A central molecule of 2 is perpendicularly interlinked

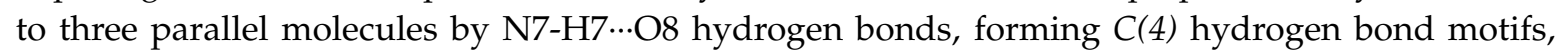
(Figure 7a). These interactions are reinforced by $\mathrm{C} 9=\mathrm{O} 9 \cdots \mathrm{C} 8=\mathrm{O} 8$ carbonyl-carbonyl interactions and $\mathrm{C} 3-\mathrm{H} 3 \cdots \mathrm{Cg}(2)$ interactions (Figure $7 \mathrm{~b}$ ), giving rise to a ribbon propagating along the direction of the $b$ axis. Hydrophobic contacts between the -OEt fragments are given between the ribbons. The whole 2D and 3D supramolecular architecture of $\mathbf{2}$ is given by the propagation of the ribbons by the N7-H7 ‥O8 hydrogen bond along in the plane $a b$, contrasting with the related compound 4,4'-oxo-bis(phenylcarbamic acid 1-methylethyl ester) [45] which forms supramolecular tapes of parallel 1:1 units via $\mathrm{N}-\mathrm{H} \cdots \mathrm{O}$ hydrogen bonds showing a $\mathrm{C}(4)$ motif. 

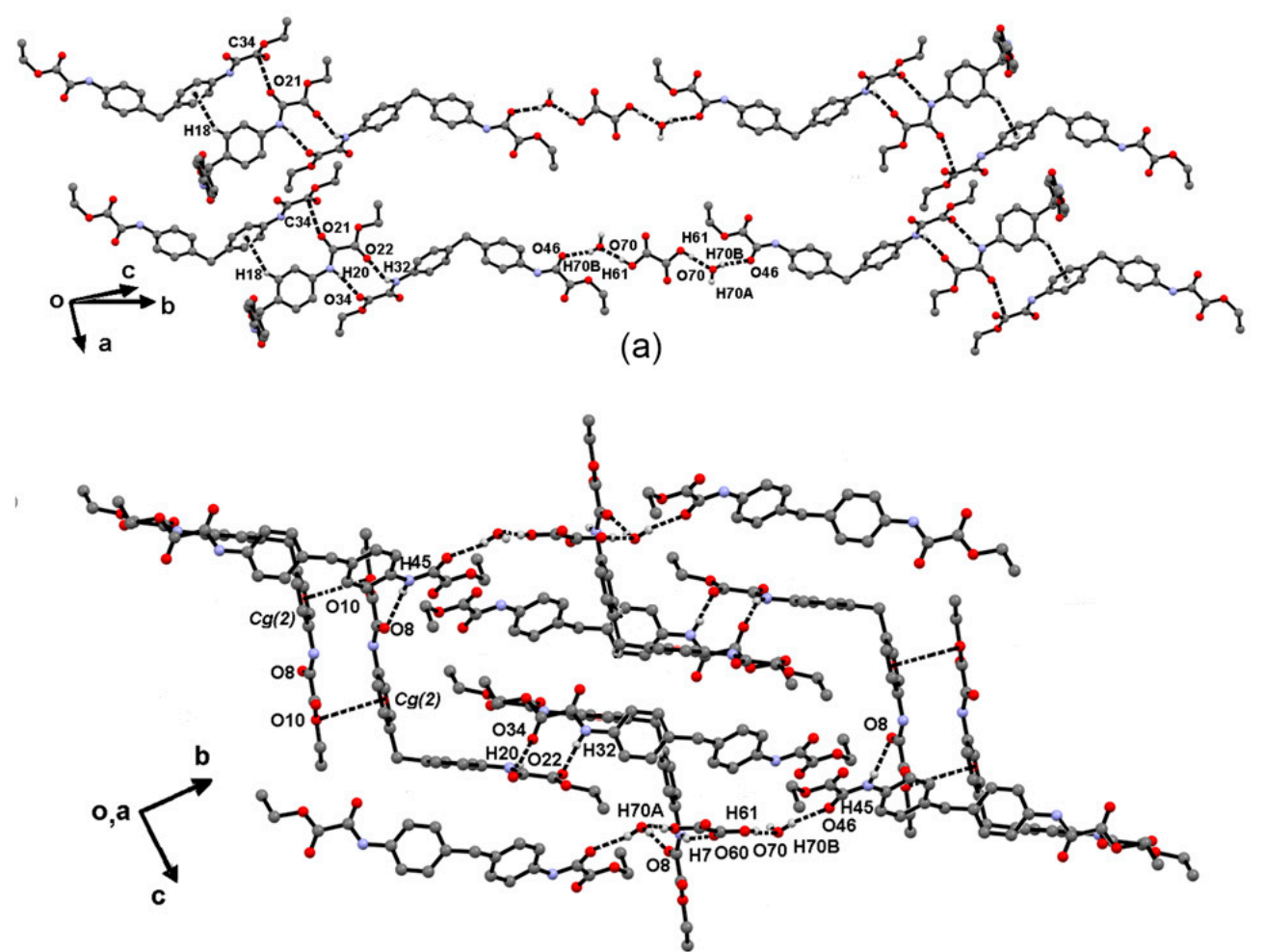

(b)

Figure 6. (a) $1 \mathrm{D}$ supramolecular tape of $\mathbf{1}_{2} \bullet \frac{1}{2}\left(\mathrm{C}_{2} \mathrm{H}_{2} \mathrm{O}_{4}\right) \bullet \mathrm{H}_{2} \mathrm{O}$ involving $\mathrm{N}-\mathrm{H} \cdots \mathrm{O}$ and $\mathrm{O}-\mathrm{H} \cdots \mathrm{O}$ hydrogen bonds, and (b) $\mathrm{C}-\mathrm{H} \cdots \pi$ and $\mathrm{C}=\mathrm{O} \cdots \mathrm{C}=\mathrm{O}$ interactions.
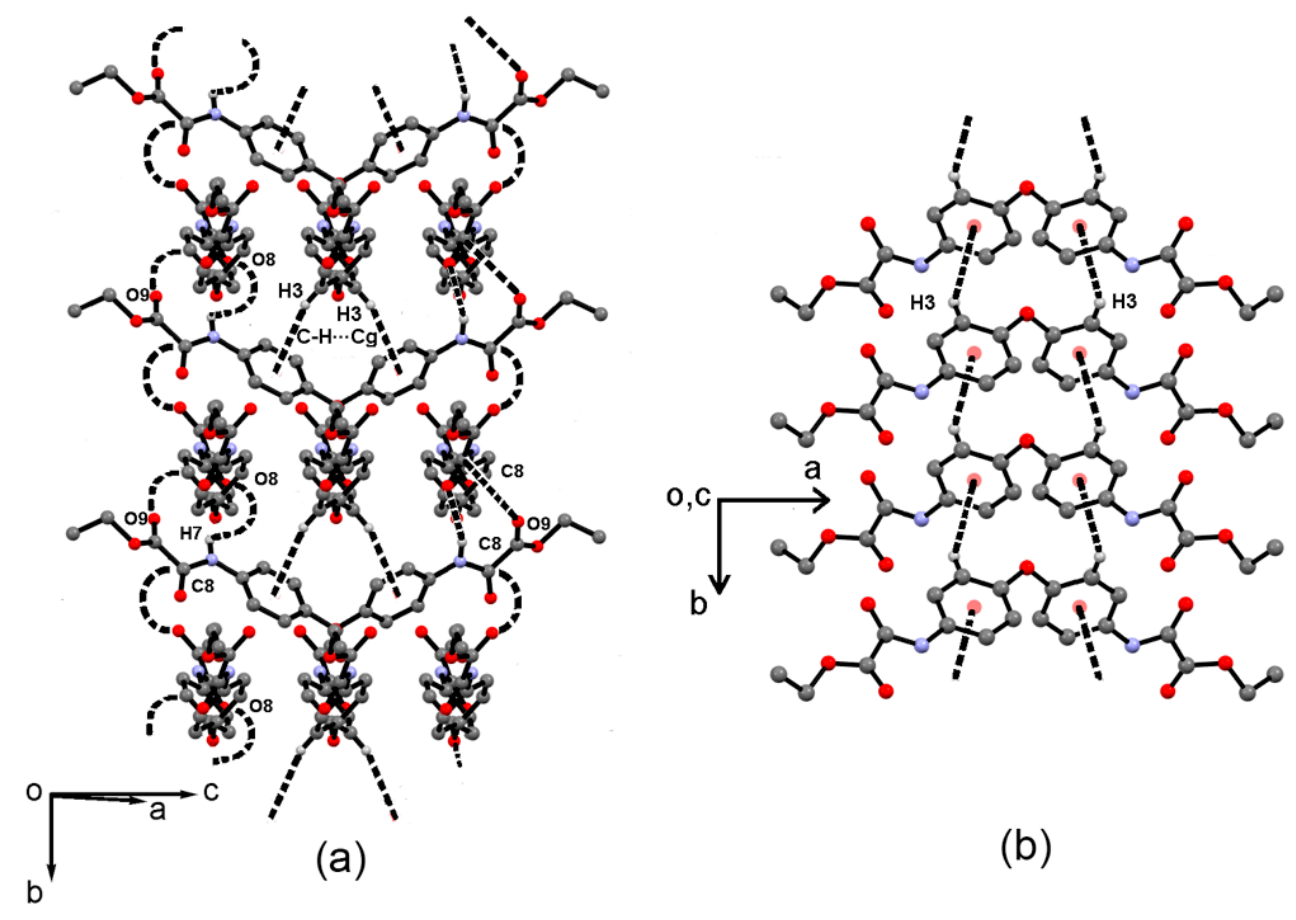

(b)

Figure 7. (a) Supramolecular cross-linked tape formed by 3:1 units of 2 running along the $b$ axis. (b) $\mathrm{C}-\mathrm{H} \cdots \pi$ interactions in 2.

The first dimensional supramolecular architecture of $\mathbf{3}$ is given by a supramolecular tape of $\mathbf{3 b}$

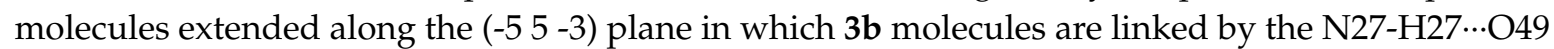
hydrogen bond and $\mathrm{C} 22-\mathrm{H} 22 \ldots \mathrm{O} 49$ interaction, forming the three-centered hydrogen bond interaction 
$\mathrm{H} 22 \cdots \mathrm{O} 49 \cdots \mathrm{H} 27$ showing a $R^{1}{ }_{2}(6)$ motif. The second dimension is given by the perpendicular zig-zagging tape of 3a molecules extended along the $(44-7)$ plane. They are linked through $\mathrm{C} 8=\mathrm{O} 8 \cdots \mathrm{C} 9$ carbonyl-carbonyl interactions $\left(\mathrm{O} 8 \cdots \mathrm{C} 9=3.128(3), \mathrm{C} 8=\mathrm{O} 8 \cdots \mathrm{C} 9\right.$ angle $\left.=111.0(2)^{\circ}\right)$ and the $\mathrm{C} 12-\mathrm{H} 12 \mathrm{C} \cdots \mathrm{Cg}(2)$ interaction, forming an angle with the tape of $\mathbf{3 b}$ molecules of $80.61^{\circ}$ (Figure 8). The presence of two different molecules of 3 in the asymmetric unit, pointing to different crystallographic directions lead to the formation of the third dimensional supramolecular array showing cross linked

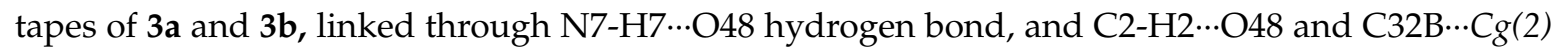
interactions (Figure 8).

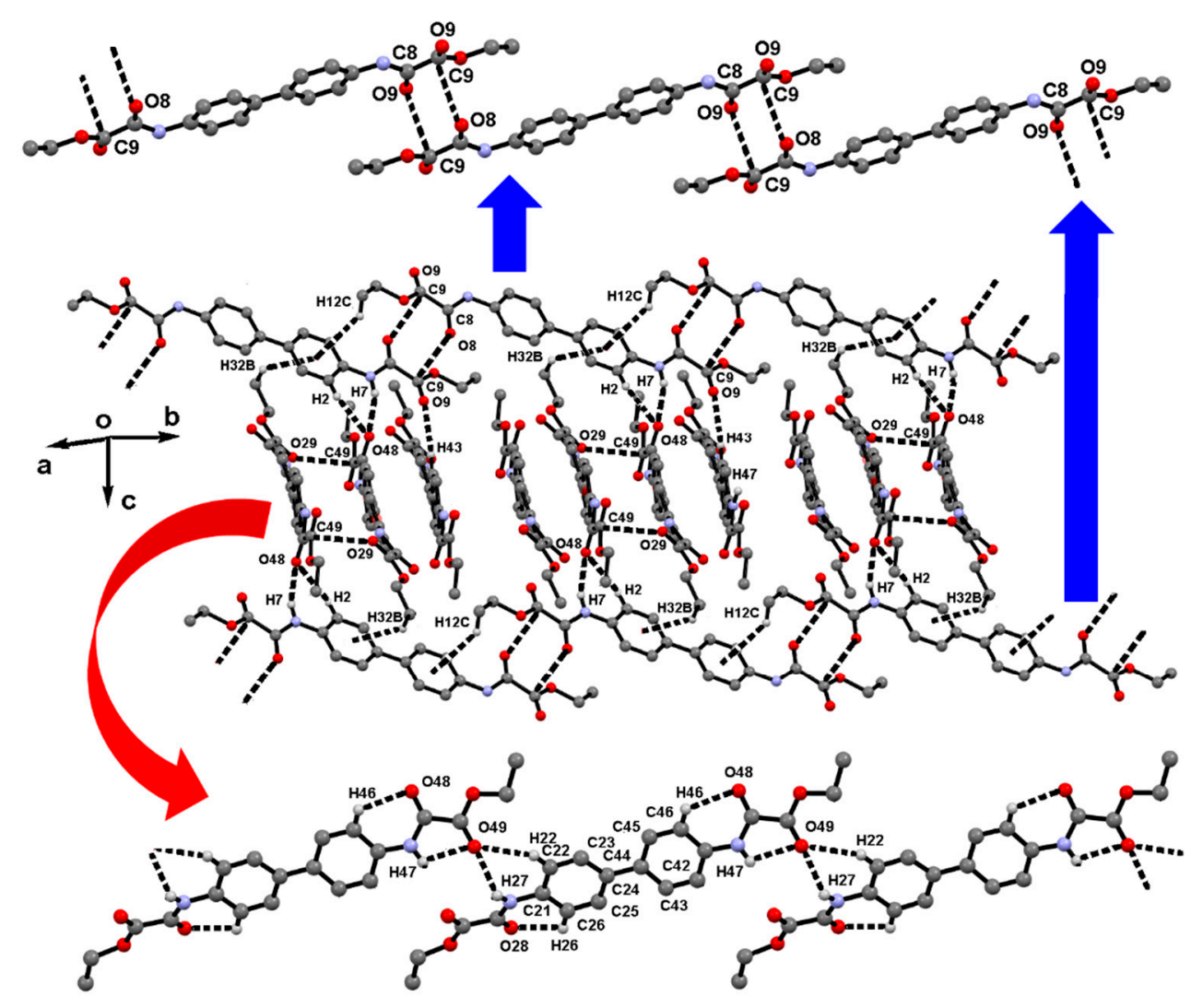

Figure 8. Supramolecular sheet of cross linked molecules of 3 formed by the $\mathrm{N}-\mathrm{H} \cdots \mathrm{O}$ hydrogen bonds, and $\mathrm{C}-\mathrm{H} \cdots \mathrm{O}, \mathrm{C}-\mathrm{H} \cdots \pi$ and $\mathrm{C}=\mathrm{O} \cdots \mathrm{C}=\mathrm{O}$ interactions.

The supramolecular architecture of 1-3 is driven by $\mathrm{N}-\mathrm{H} \cdots \mathrm{O}=\mathrm{C}$ hydrogen bonds and reinforced by $\mathrm{C}=\mathrm{O} \cdots \mathrm{C}=\mathrm{O}$ and $\mathrm{C}-\mathrm{H} \cdots \pi$. It is worth to note the preference of $\mathbf{1}$ and $\mathbf{3}$ to form cross-linked supramolecular architectures because of the presence of two independent molecules in the asymmetric unit, as well as co-crystallization with oxalic acid and water molecules, in the case of compound $\mathbf{1}$.

\subsection{DFT Calculations and Hirshfeld Surface Analysis}

In order to understand the effect of supramolecular interactions in the crystal packing, the geometric optimization of structures 1-3 in anti and syn conformation was carried out (Figure 9). The calculations were performed both in gas phase. 
1

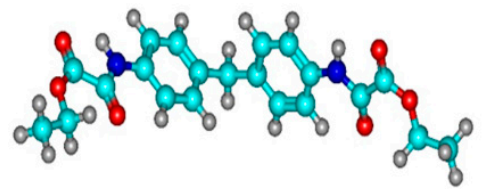

2

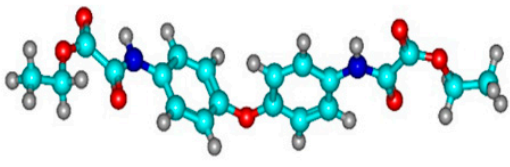

3

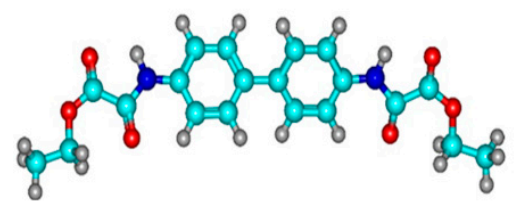

(a)
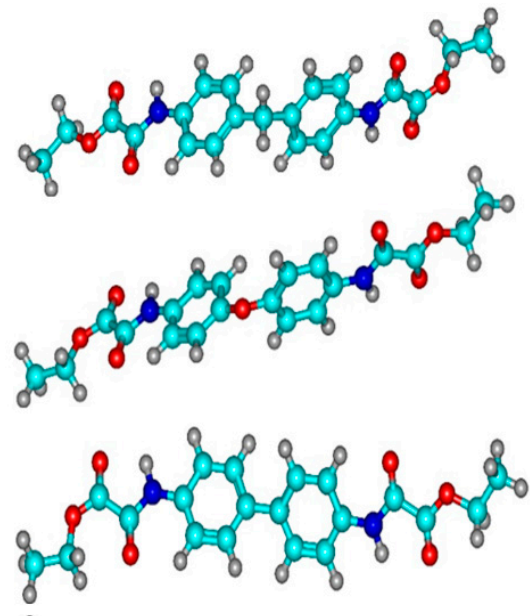

(b)

Figure 9. Optimized structures of 1-3 molecules in syn (a) and anti (b) conformation in the gas phase. Optimized structures were obtained at a wB97X-D3/def2-TZVP level theory.

Theoretical calculations revealed that the anti-conformation is the most favorable for compounds 1-3, being the average energy difference between the syn and anti forms of $5.578 \mathrm{kcal} / \mathrm{mol}$, in the gas phase (Table 3). However, compounds 1 and 2 adopt the energetically unfavorable syn conformation, and compound 3, the anti. Thus, non-covalent interactions determine the conformation adopted by compounds 1-3 and direct the crystal packing.

Table 3. Relative energies ( $\mathrm{kcal} / \mathrm{mol})$ for the syn and anti conformations for 1-3.

\begin{tabular}{ccc}
\hline \multirow{2}{*}{ Compound } & \multicolumn{2}{c}{ In Gas Phase (kcal/mol) } \\
\cline { 2 - 3 } & syn & anti \\
\hline $\mathbf{1}$ & 5.611 & 0 \\
$\mathbf{2}$ & 5.617 & 0 \\
$\mathbf{3}$ & 5.505 & 0 \\
\hline
\end{tabular}

The intramolecular hydrogen bonds lengths in syn and anti were also analyzed (Table 4). All the calculated data are very close to the hydrogen bonding distances found in crystals 1-3 (Table S2 Supporting Materials), obtaining the best results in the optimizations with CPCM, in all systems $S(5)$ motifs were found.

Table 4. Average intramolecular hydrogen bonds lengths (Å) in 1-3 of DFT optimized structures.

\begin{tabular}{|c|c|c|}
\hline \multirow{2}{*}{ Molecule/Interaction } & \multicolumn{2}{|c|}{ Gas Phase (Å) } \\
\hline & syn & anti \\
\hline 1 & & \\
\hline N7-H7…O9 & 2.060 & 2.104 \\
\hline 2 & & \\
\hline N7-H7...O9 & 2.059 & 2.102 \\
\hline 3 & & \\
\hline N7-H7...O9 & 2.059 & 2.103 \\
\hline
\end{tabular}

Hirshfeld surface study and 2D fingerprints of 1-3 were carried out in order to obtain information about intermolecular contacts and their quantitative contribution the supramolecular self-assembly of 1-3 [35]. Figure 10 shows the Hirshfeld surfaces, shape indexes, and curvednesses of 1-3. 


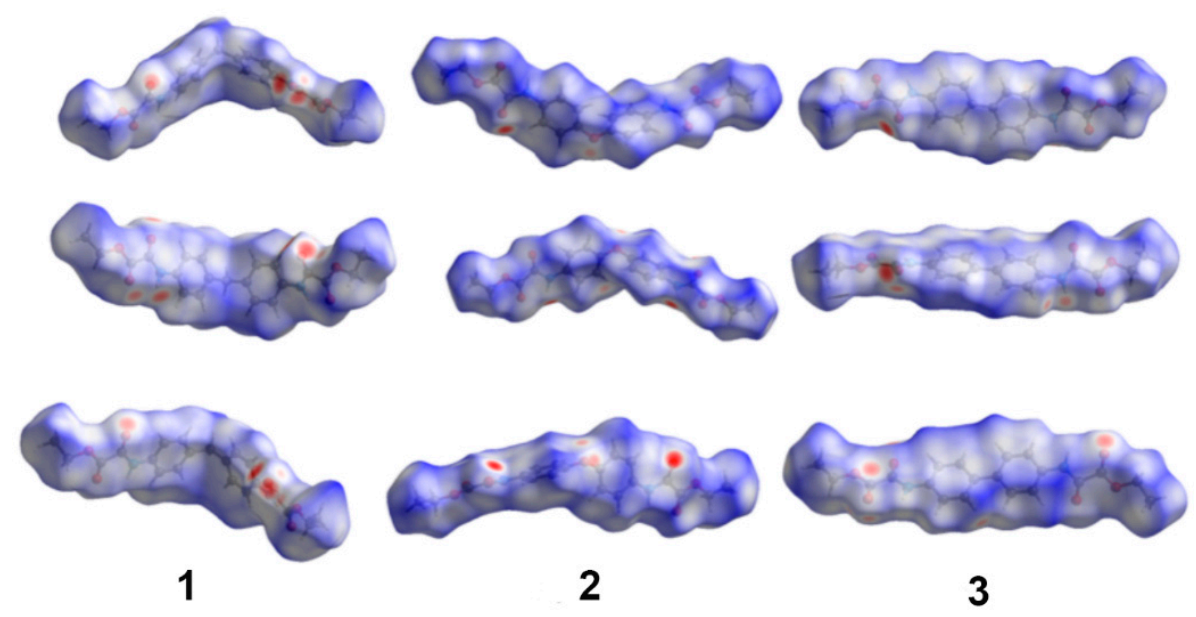

Figure 10. Hirshfeld surfaces from different perspectives for crystal structures 1-3.

Short contacts corresponding to $\mathrm{N}-\mathrm{H} \cdots \mathrm{O}=\mathrm{C}$ hydrogen bonds are represented by big red dots, indicating the $\mathrm{H}$-bond contacts are consistent with the experimental results. The fingerprint plots showed that the $\mathrm{H} \cdots \mathrm{H}$ contacts (interactions of ethyl groups with protons from the neighboring molecules) make the largest contribution to the Hirshfeld surface of 1-3 (Figures S1-S3 Supporting Materials). The $\mathrm{O} \cdots \mathrm{H}$ contacts are the second dominant interactions; this is in agreement with the crystal structures, since the $\mathrm{C}=\mathrm{O} \cdots \mathrm{H}-\mathrm{N}, \mathrm{C}-\mathrm{H} \cdots \mathrm{O}=\mathrm{C}$ hydrogen bonds drive the supramolecular assemblies. $\mathrm{C}-\mathrm{H}$ contacts in the form of $\mathrm{C}-\mathrm{H} \cdots \pi$ interactions and $\mathrm{C} \cdots \mathrm{O}$ contacts in the form of $\mathrm{C}=\mathrm{O} \cdots \mathrm{C}=\mathrm{O}$ interactions, complete the principal contributions to the Hirshfeld surfaces (Figure 11).

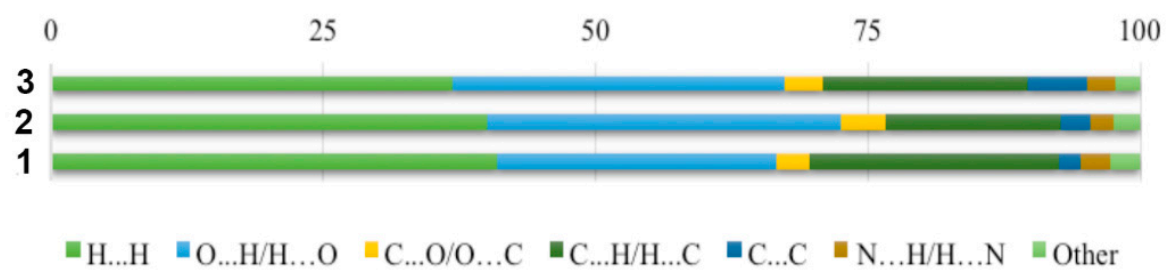

Figure 11. Relative contributions to the Hirshfeld surfaces for the major intermolecular contacts in 1-3.

\section{Conclusions}

The $\mathrm{N}-\mathrm{H} \cdots \mathrm{O}=\mathrm{C}$ hydrogen bond is the interaction that drives the supramolecular assemblies in 1-3, and is reinforced by $\mathrm{C}-\mathrm{H} \cdots \mathrm{O}=\mathrm{C}, \mathrm{C}-\mathrm{H} \cdots \pi$ and $\mathrm{C}=\mathrm{O} \cdots \mathrm{C}=\mathrm{O}$ interactions. The three compounds showed cross-linked supramolecular architecture, caused by the presence of two different molecules in the unit cell of 1 and 3 , and the $C_{2}$ symmetry in 2 .

The presence of oxalic acid and water in the unit cell of $\mathbf{1}$ as consequence of the cocrystal formation, offer a greater possibility of formation of intermolecular interactions.

The syn conformation is preferred in $\mathbf{1}$ and $\mathbf{2}$, meanwhile compound $\mathbf{3}$ adopts the less stable anti conformation, indicating that non-covalent interactions determine the conformation adopted by compounds 1-3 and direct the crystal packing.

Hirshfeld surface study revealed that the $\mathrm{H} \cdots \mathrm{H}, \mathrm{O} \cdots \mathrm{H}, \mathrm{C} \cdots \mathrm{O}$ and $\mathrm{C} \cdots \mathrm{H}$ interactions stabilize the supramolecular self-assembly of 1-3.

Supplementary Materials: The following are available online at http://www.mdpi.com/2073-4352/10/11/1048/s1, Materials and instrumentation; Synthesis and characterization of 1-3; Table S1. Selected bond distances ( $(\AA)$ and angles (deg) for 1-3; Table S2. Intramolecular interactions in $\mathbf{1}_{\mathbf{2}} \bullet \frac{\mathbf{1}}{\mathbf{2}}\left(\mathbf{C}_{\mathbf{2}} \mathbf{H}_{\mathbf{2}} \mathbf{O}_{\mathbf{4}}\right) \bullet \mathbf{H}_{\mathbf{2}} \mathbf{O}, \mathbf{2}$ and 3; Figure S1. Fingerprints plots of the total and specific intermolecular contacts of 1; Figure S2. Fingerprints plots of the total and specific intermolecular contacts of 2; Figure S3. Fingerprints plots of the total and specific intermolecular contacts of 3. 
Author Contributions: Conceptualization, manuscript writing, reviewing and editing, F.J.M.-M., I.I.P.-M., J.S.G.-G.; methodology, J.S.G.-G.; formal analysis, E.V.G.-B., N.E.M.-V.; software J.P.M.-S. All authors have read and agreed to the published version of the manuscript.

Funding: This research was funded by Universidad de la Cañada, grant number PFI-05/17. CONACYT, grant number 255354 and Secretaría de Investigación y Posgrado del Instituto Politécnico Nacional (SIP-IPN). CONACYT "Red Temática de Química Supramolecular" Grant 271884. CGIC-UC (Coordinación General de Investigación Científica de la Universidad de Colima) and PRODEP-SEP.

Conflicts of Interest: The authors declare no conflict of interest.

\section{References}

1. Ono, S.J.; Abelson, M.B. Allergic conjunctivitis: Update on pathophysiology and prospects for future treatment. J. Allergy Clin. Immunol. 2005, 115, 118-122. [CrossRef]

2. La Rosa, M.; Lionetti, E.; Reibaldi, M.; Russo, A.; Longo, A.; Leonardi, S.; Tomarchio, S.; Avitabile, T.; Reibaldi, A. Allergic conjunctivitis: A comprehensive review of the literature. Italian J. Pediatr. 2013, 39, 18. [CrossRef]

3. Das, D.; Khan, M.; Gul, A.; Alam, R. Safety and efficacy of Lodoxamide in vernal keratoconjunctivitis. J. Pak. Med. Assoc. 2011, 61, 239-241.

4. Padilla-Martínez, I.I.; Chaparro-Huerta, M.; Martínez-Martínez, F.J.; Höpfl, H.; García-Báez, E.V. Diethyl N,N'-m-phenyl-enedioxamate. Acta Crystallogr. Sect. E Struct. Rep. Online 2003, 59, o825-o827. [CrossRef]

5. González-González, J.S.; Martínez-Martínez, F.J.; Peraza-Campos, A.L.; Rosales-Hoz, M.J.; García-Báez, E.V.; Padilla-Martínez, I.I. Supramolecular architectures of conformationally controlled 1,3-phenyl-dioxalamic molecular clefts through hydrogen bonding and steric restraints. CrystEngComm 2011, 13, 4748-4761. [CrossRef]

6. González-González, J.S.; Padilla-Martínez, I.I.; García-Báez, E.V.; Franco-Hernández, O.; Martínez-Martínez, F.J. Helical supramolecular assembly of $N^{2}, N^{2}$-bis[3-(morpholin-4-yl)propyl]- $N^{1}, N^{1^{\prime}}-(1,2-$ phenylene)dioxalamide dimethyl sulfoxide monosolvate. Acta Crystallogr. Sect. C Cryst. Struct. Commun. 2013, 69, 66-69. [CrossRef]

7. González-González, J.S.; Martínez-Martínez, F.J.; García-Báez, E.V.; Cruz, A.; Morín-Sánchez, L.M.; Rojas-Lima, S.; Padilla-Martínez, I.I. Molecular Complexes of diethyl n, n'-1,3-phenyldioxalamate and resorcinols: Conformational switching through intramolecular three-centered hydrogen-bonding. Cryst. Growth Des. 2014, 14, 628-642. [CrossRef]

8. González-González, J.S.; Zúñiga-Lemus, O.; Martínez-Martínez, F.J.; González, J.; García-Báez, E.V.; Padilla-Martínez, I.I. Mechanochemical complexation of diethyl $N, N^{\prime}-[1,3-(2-m e t h y l) p h e n y l] d i o x a l a m a t e$ and resorcinol: Conformational twist and x-ray helical supramolecular architecture. J. Chem. Crystallogr. 2015, 45, 244-250. [CrossRef]

9. Ramírez-Milanés, E.G.; Martínez-Martínez, F.J.; Magaña-Vergara, N.E.; Rojas-Lima, S.; Avendaño-Jiménez, Y.A.; García-Báez, E.V.; Morín-Sánchez, L.M.; Padilla-Martínez, I.I. Positional isomerism and steric effects in the self-assemblies of phenylene bis-monothiooxalamides. Cryst. Growth Des. 2017, 17, 2513-2528. [CrossRef]

10. Blay, G.; Fernández, I.; Pedro, J.R.; Ruiz-García, R.; Muñoz, M.C.; Cano, J.; Carrasco, R. A Hydrogen-bonded supramolecular meso-helix. Eur. J. Org. Chem. 2003, 2003, 1627-1630. [CrossRef]

11. Martín, S.; Beitia, J.I.; Ugalde, M.; Vitoria, P.; Cortes, R. Diethyl N,N’o-phenylenedioxamate. Acta Crystallogr. Sect. E Struct. Rep. Online 2002, 58, o913-0915. [CrossRef]

12. Yang, W.; Liu, X. Diethyl N,N'-(p-phenylene)dioxamate. Acta Crystallogr. Sect. E Struct. Rep. Online 2008, 64, o1852. [CrossRef]

13. Oliveira, W.X.C.; Pinheiro, C.B.; da Costa, M.M.; Fontes, A.P.S.; Nunes, W.C.; Lloret, F.; Julve, M.; Pereira, C.L.M. Crystal engineering applied to modulate the structure and magnetic properties of oxamate complexes containing the $[\mathrm{Cu}(\mathrm{bpca})]^{+}$Cation. Cryst. Growth Des. 2016, 16, 4094-4107. [CrossRef]

14. Lisnard, L.; Chamoreau, L.-M.; Li, Y.; Journaux, Y. Solvothermal synthesis of oxamate-based helicate: Temperature dependence of the hydrogen bond structuring in the solid. Cryst. Growth Des. 2012, 12, 4955-4962. [CrossRef] 
15. Dul, M.C.; Pardo, E.; Lescouëzec, R.; Journaux, Y.; Ferrando-Soria, J.; Ruiz-García, R.; Cano, J.; Julve, M.; Lloret, F.; Cangussue, D.; et al. Supramolecular coordination chemistry of aromatic polyoxalamide ligands: A metallosupramolecular approach toward functional magnetic materials. Coord. Chem. Rev. 2010, 254, 2281-2296. [CrossRef]

16. Miljanic, S.; Frkanec, L.; Meic, Z.; Zinic, M. Gelation ability of novel oxamide-based derivatives bearing a stilbene as a photo-responsive unit. Eur. J. Chem. 2006, 2006, 1323-1334. [CrossRef]

17. Chong-Canto, S.; García-Báez, E.V.; Martínez-Martínez, F.J.; Ramos-Organillo, A.A.; Padilla-Martínez, I.I. Mechanochemical synthesis and structure of the tetrahydrate and mesoporous anhydrous metforminium(2+)- $N, N^{\prime}-1,4$-phenylenedioxalamic acid (1:2) salt: The role of hydrogen bonding and $n-p^{*}$ charge assisted interactions. Pharmaceutics 2020, 12, 998. [CrossRef]

18. Basu, A.; Anasua Sarkar, A.; Basak, P. Immunoinformatics study of procyanidins as mast cell stabilizers. Pharmacogn. J. 2018, 10, 814-817. [CrossRef]

19. Eggel, A.; Baravalle, G.; Hobi, G.; Kim, B.; Buschor, P.; Forrer, P.; Shin, J.S.; Vogel, M.; Stadler, B.M.; Dahinden, C.A.; et al. Accelerated dissociation of IgE-FceRI complexes by disruptive inhibitors actively desensitizes allergic effector cells. J. Allergy Clin. Immunol. 2014, 133, 1709-1719. [CrossRef]

20. Sellstedt, J.H.; Guinosso, C.J.; Begany, A.J.; Bell, S.C.; Rosenthale, M. Oxanilic acids, a new series of orally active antiallergic agents. J. Med. Chem. 1975, 18, 926-933. [CrossRef]

21. Hall, C.M.; Wright, J.B. Anti-Allergic Oxanilate Compounds. U.S. Patent 4,061,791, 6 December 1977.

22. McDonald, R. Reaction of oxalyl chloride with amine hydrochlorides. J. Org. Chem. 1959, 24, 1580-1581. [CrossRef]

23. Spackman, M.A.; Jayatilaka, D. Hirshfeld surface analysis. CrystEngComm 2009, 11, 19-32. [CrossRef]

24. Bruker, A.X.S. APEX2, SAINT and SADABS; Bruker AXS Inc.: Madison, WI, USA, 2008.

25. Sheldrick, G.M. A short history of SHELX. Acta Crystallogr. Sect. A Found. Crystallogr. 2008, 64, 112-122. [CrossRef] [PubMed]

26. Macrae, C.F.; Bruno, I.J.; Chisholm, J.A.; Edgington, P.R.; McCabe, P.; Pidcock, E.; Rodriguez-Monge, L.; Taylor, R.; van de Streek, J.; Wood, P.A. Mercury CSD 2.0-new features for the visualization and investigation of crystal structures. J. Appl. Cryst. 2008, 41, 466-470. [CrossRef]

27. Sheldrick, G.M. Crystal Structure Refinement with SHELXL. Acta Cryst. 2015, C71, 3-8. [CrossRef]

28. Neese, F. The ORCA program system. Wiley Interdiscip. Rev. Comput. Mol. Sci. 2012, 2, 73-78. [CrossRef]

29. Weigend, F.; Ahlrichs, R. Balanced basis sets of split valence, triple zeta valence and quadruple zeta valence quality for $\mathrm{H}$ to $\mathrm{Rn}$ : Design and assessment of accuracy. Phys. Chem. Chem. Phys. 2005, 7, 3297-3305. [CrossRef]

30. Holzmann, N.; Stasch, A.; Jones, C.; Frenking, G. Structures and stabilities of group 13 adducts [(NHC)(EX3)] and $[(\mathrm{NHC}) 2(\mathrm{E} 2 \mathrm{Xn})](\mathrm{E}=\mathrm{B}$ to In; $\mathrm{X}=\mathrm{H}, \mathrm{Cl} ; \mathrm{n}=4,2,0 ; \mathrm{NHC}=\mathrm{N}-$ Heterocyclic Carbene) and the search for hydrogen storage systems: A theoretical study. Chem. Eur. J. 2011, 17, 13517-13525. [CrossRef]

31. Lin, Y.S.; Li, G.D.; Mao, S.P.; Chai, J.D. Long-range corrected hybrid density functionals with improved dispersion corrections. J. Chem. Theory Comput. 2013, 9, 263-272. [CrossRef]

32. Baldridge, K.; Klamt, A. First principles implementation of solvent effects without outlying charge error. J. Chem. Phys. 1997, 106, 6622-6633. [CrossRef]

33. Takano, Y.; Houk, K.N. Benchmarking the conductor-like polarizable continuum model (CPCM) for aqueous solvation free energies of neutral and ionic organic molecules. J. Chem. Theory Comput. 2005, 1, 70-77. [CrossRef]

34. Zhurko, G.A.; Zhurko, D.A. Chemcraft Program, Academic Version 1.8. 2009. Available online: https: //www.chemcraftprog.com (accessed on 18 November 2020).

35. Turner, M.J.; McKinnon, J.J.; Wolff, S.K.; Grimwood, D.J.; Spackman, P.R.; Jayatilaka, D.; Spackman, M.A. Crystal Explorer 3.1; The University of Western Australia: Perth, Australia, 2017.

36. Koga, T.; Kanayama, K.; Thakkar, A.J. Noninteger principal quantum numbers increase the efficiency of Slater-type basis sets. Chem. Phys. Lett. 1997, 62, 1-11. [CrossRef]

37. Rodríguez, O.A.R.; Vergara, N.E.M.; Sánchez, J.P.M.; Martínez, M.T.S.; Sandoval, Z.G.; Cruz, A.; Organillo, A.R. Synthesis, crystal structure, antioxidant activity and dft study of 2-aryl-2,3dihydro-4H-[1,3]thiazino[3,2-a]benzimidazol-4-One. J. Mol. Struct. 2020, 1199, 127036. [CrossRef]

38. Bernstein, J.; Davis, R.E.; Shimoni, L.; Chang, N.L. Patterns in Hydrogen Bonding: Functionality and Graph Set Analysis in Crystals. Angew. Chem. Int. Ed. Engl. 1995, 34, 1555-1573. [CrossRef] 
39. Meghdadi, S.; Khavasi, H.R.; Nalchigar, S. N,N'-(Methyl-enedi-p-phenylene)bis(pyridine-2-carboxamide). Acta Crystallogr. Sect. E Struct. Rep. Online 2006, 62, o5492-05493. [CrossRef]

40. Gardner, K.H.; Blackwell, J. Structure of dimethyl 4,4'-methylenebis(phenylcarbamate): A model for MDI units in polyurethane hard segments. Acta Crystallogr. Sect. B Struct. Crystallogr. Cryst. Chem. 1980, 36, 1972-1975. [CrossRef]

41. Steiner, T. The Hydrogen Bond in Solid State. Angew. Chem. Int. Ed. Engl. 2002, 41, 48-76. [CrossRef]

42. Desiraju, G.R. The C-H...O Hydrogen Bond: Structural Implications and Supramolecular Design. Acc. Chem. Res. 1996, 29, 441-449. [CrossRef]

43. Nishio, M. CH/interactions hydrogen bonds in crystals. CrystEngComm 2004, 6, 130-158. [CrossRef]

44. Allen, F.H.; Baalham, C.A.; Lommerse, J.P.M.; Raithby, P.R. Carbonyl-Carbonyl Interactions can be Competitive with Hydrogen Bonds. Acta Crystallogr. Sect. B Struct. Sci. 1998, B54, 320-329. [CrossRef]

45. Wang, W.Z.; Fan, N.T. Synthesis and Crystal Structure of 4,4'-Oxobis(propham). Acta Phys. Chim. Sin. 2003, 19, 75-78. [CrossRef]

Publisher's Note: MDPI stays neutral with regard to jurisdictional claims in published maps and institutional affiliations.

(C) 2020 by the authors. Licensee MDPI, Basel, Switzerland. This article is an open access article distributed under the terms and conditions of the Creative Commons Attribution (CC BY) license (http://creativecommons.org/licenses/by/4.0/). 